\title{
CLAIMING AND DEFENDING ABORTION RIGHTS IN SOUTH AFRICA
}

\begin{abstract}
The South African transition to democracy ENABLED SUCCESSFUL CLAIMS FOR GENDER EQUALITY AND REPRODUCTIVE RIGHTS IN THE CONSTITUTION AND IN LAW. THIS ARTICLE EXPLORES THAT TRANSITION WITH A FOCUS ON THE ENACTMENT OF A PROGRESSIVE ABORTION LAW; THE FEMINIST, RIGHTS AND PUBLIC HEALTH NARRATIVES THAT JUSTIFIED IT; AND THE MANNER IN WHICH IT TRANSFORMED CONSTITUTIONAL AND LEGAL NORMS ABOUT WOMEN AND REPRODUCTIVE CHOICE, DESPITE A BROADLY CONSERVATIVE SOCIETY. THEN, IT DISCUSSES TWENTY YEARS OF THE ACT IN PRACTICE, HIGHLIGHTING ITS UNEVEN IMPLEMENTATION IN THE FACE OF SIGNIFICANT NORMATIVE RESISTANCE AND CHANGING NARRATIVES, IT ALSO DESCRIBES THE EBB AND FLOW OF RIGHTS PROTECTION IN CHANGING SOCIAL AND POLITICAL CONDITIONS, AND DEMONSTRATES THE IMPORTANCE OF CONSTITUTIONAL AND LEGAL GUARANTEES TO ABORTION AS A BULWARK AGAINST THEIR EROSION. AT THE SAME TIME, IT ILLUSTRATES THE IMPORTANCE OF POLITICAL WILL, FEMINIST NARRATIVES AND CIVIL SOCIETY ACTIVISM IN MAINTAINING EFFECTIVE ACCESS TO SAFE, LEGAL ABORTION FOR POOR, BLACK, WORKING CLASS AND RURAL WOMEN.
\end{abstract}

PALAVRAS-CHAVE

ABORTION; EQUALITY; REPRODUCTIVE JUSTICE; CHOICE; RIGHTS

\author{
Cathi Albertyn
}

REIVINDICANDO E DEFENDENDO O DIREITO AO ABORTO

REIVINDICANDO E DEFENDENDO O DIREITO AO ABORTO
NA ÁFRICA DO SUL

\section{RESUMO}

A TRANSIÇÃO SUL-AFRICANA PARA A DEMOCRACIA PERMITIU REIVINDICACÕES DE SUCESSO PARA A IGUALDADE DE GÊNERO E DIREITOS REPRODUTIVOS NA CONSTITUICÃO E NA LEI. ESTE ARTIGO EXPLORA ESSA TRANSIC̣ÃO COM O ENFOQUE SOBRE A PROMULGACÃO DE LEI PROGRESSIVA SOBRE ABORTO; O FEMINISMO, DIREITOS E AS NARRATIVAS DE SAÚDE PÚBLICA QUE A JUSTIFICARAM; E A MANEIRA COM A QUAL TRANSFORMOU NORMAS CONSTITUCIONAIS E LEGAIS SOBRE AS MULHERES E A ESCOLHA REPRODUTIVA, APESAR DA SOCIEDADE AMPLAMENTE CONSERVADORA EM QUE FOI CONSTRUÍDA. EM SEGUIDA, DISCUTE-SE A VIGÊNCIA DE VINTE ANOS DA LEI, COM DESTAQUE PARA A SUA IMPLEMENTACCÃO DESIGUAL EM FACE DA SIGNIFICATIVA RESISTÊNCIA NORMATIVA E DE NARRATIVAS MUTÁVEIS. DESCREVE-SE TAMBÉM O FLUXO E REFLUXO DA PROTEÇÃO DOS DIREITOS NA MUDANCA DE CONDICÕES SOCIAIS E POLITICAS E DEMONSTRA-SE A IMPORTÂNCIA DAS GARANTIAS CONSTITUCIONAIS E LEGAIS PARA O ABORTO COMO UM BALUARTE CONTRA A SUA EROSÃO. AO MESMO TEMPO, OBSERVA-SE A IMPORTÂNCIA DA VONTADE POLITICA, DAS NARRATIVAS FEMINISTAS E DO ATIVISMO DA SOCIEDADE CIVIL NA MANUTENCCÃO DE UM ACESSO EFETIVO AO ABORTO SEGURO E LEGAL PARA AS MULHERES POBRES, PRETAS E DAS CLASSES TRABALHADORA E RURAL.

\section{PALAVRAS-CHAVE}

ABORTO; IGUALDADE; JUSTICA REPRODUTIVA; ESCOLHA; DIREITOS. 


\section{INTRODUCTION}

In the early 1990s, the South African transition to democracy created space for women to make successful claims for equality and reproductive choice in the new constitution and in the law. South Africa was not alone in recognising reproductive rights, as many constitutions of the 'third wave' of democratisation in Africa and South America paid particular attention to women's rights. In countries such as Colombia, Uruguay and South Africa, this provided a conceptual framework for differing levels of abortion law reform in parliaments, courts and practice. However, South Africa arguably stands out for the robust nature of its formal rights framework and has been globally praised for the substantive protection given to reproductive rights in its 1996 Constitution, and its Choice on Termination of Pregnancy Act, 92 of 1995, (CTOPA). This transformed the legal framework for abortion from limited access, defined by race and class and policed by medical necessity and the criminal law, to a rights-based framework that effectively enables abortion on request up to 20 weeks of pregnancy.

In this article, I argue that the rights framework established in the early $1990 \mathrm{~s}$ was driven by both feminist and public health concerns, and had significant transformative potential in shifting public norms of women, reproductive choice and gender equality; as well as establishing an enabling framework for implementation of the CTOPA; and finally providing safe legal abortions for a growing number of women. Disappointingly, in recent years, these advances have been pushed back in the face of a declining health-system, pervasive stigma and normative resistance, a less visible non-governmental sector and unclear political will. It is little surprise to learn that poor, black women have bore the brunt of this, once more putting their lives and health at risk in unsafe backstreet abortions.

On the first part of this article, to contextualise these developments, I describe the meaning of abortion under apartheid and the dominance of pro-life, medical necessity and conservative moral narratives, before turning to the achievements triggered by the transition to democracy in the early 1990 s. I identify these conditions that enabled the substantive constitutional and legal changes of this period and the multiple narratives that surrounded them. As a result, I suggest that the feminist narratives on abortion capture an incipient and transformative rights framework of reproductive justice that is a significant gain, despite the ebb and flow of actual protection. This idea of reproductive justice lies in a mutually reinforcing and substantive relationship between freedom and equality, which requires careful attention to the social, economic, legal and political conditions that limit or enable reproductive choice, especially for the most vulnerable and marginalised women.

On the second part, after discussing the enactment of the CTOPA, I turn to the nature and scope of progress under the CTOPA over the past twenty years. At this point, I consider the important advances in access to safe terminations for women, 
as well as the growing problems of implementation that limit access to safe legal abortions and influence women's resort to illegal backstreet abortions. Alongside this, I investigate how the CTOPA and its underlying narratives have been limited, challenged and defended in court, parliament and society, including how new pro-life narratives have emerged to counter feminist arguments. Turning to the present-day, I identify deepening problems of implementation and the emergence of contested political will within the state. On the third part, I briefly speculate as to whether the conditions might be present for the consolidation of the idea of reproductive justice within a context of 'radical socio-economic transformation' and how this might provide new impetus for civil society advocacy, also with the state's ability and willingness to provide an universal access to reproductive health-care, including abortion. Finally, my conclusion brings an emphasis to the key South African lessons of claiming and defending abortion rights.

\section{COMPETING NARRATIVES AND CHANGING CONTEXTS OF ABORTION:} FROM PATRIARCHY TO REPRODUCTIVE RIGHTS

Reproductive decision-making and abortion have been subject to different forms of legal and normative regulation in South African history, for example, the inherited colonial common law, the Abortion and Sterilisation Act, 2 of 1975, enacted by the Apartheid government, and the CTOPA under democracy. Either one or the other has taken place in different socio-political conditions, has been driven by different interest groups and has been shaped by changing ideas of gender, women and the regulation of reproductive choice. In America's context, Greenhouse and Siegel have argued that the meaning of abortion shifts continuously, as it is incessantly justified and contested by different and changing frames or narratives (2012, p. 268). The authors identify, inter alia, medical necessity and public health arguments, feminist arguments relating to sexual freedom, equality, and pro-life arguments. Similarly in South Africa, different laws have been introduced and challenged by a variety of conflicting and complementary narratives. This section describes the difference between contexts and meanings of abortion that surrounded the passage of both the 1975 Abortion and Sterilisation Act and the CTOPA, and explores the conditions under which feminist public health and rights-based arguments were able to secure a progressive abortion law.

\section{i. I Abortion under Apartheid}

From colonial times, abortion had been permitted to save the life of the mother, although there was some uncertainty about its exact status in the common law (NGWENA, 1998; NGWENA, 2004, p. 712). Driven by government's concern with the spread of 'permissiveness' in white society and a desire to regulate the sexuality 
of young white women (KLAUSEN, 2010), health professionals who faced criminal prosecution for acting outside the unclear boundaries of the common law, the 1975 Abortion and Sterilisation Act clarified and extended the law by legalising a limited range of therapeutic abortions under the control of these professionals. Section 3 of that Act permitted abortion, where it was medically indicated for a woman (the presence of physiological or mental health indicators adjudicated by medical practitioners) or fetus (a serious risk of physical or mental defect), or in circumstances of non-consensual sex, called rape or incest. ${ }^{1}$ However, abortions were made subject to stringent medical and legal procedures. Thus, in terms of sections 3 and 6 , any abortion required the approval of two independent physicians, one of whom should be a state registered psychiatrist physician, if the abortion was sought on mental health grounds. Abortion on the grounds of incest or rape could only be granted with a certificate from a local magistrate.

The dominant narratives of the time combined moral censure with medical necessity. Indeed, the government emphatically opposed abortion on demand, illegitimate births and extra-marital pregnancies. It asked that the law should register respect for the unborn child, recognise South Africa's Christian views and strict moral norms, and ensure drastic action against women, who sought abortions outside of the law (HANSARD, 18 February 1973, col. 1448). For the medical professionals who drove the legal reform, abortion was justified not as a woman's right but as a medical necessity. The dominant public discourses appeared to be 'pro-life', sustained by notions of 'murdering unborn children' and promiscuous women who resorted to abortion as a form of contraception. At a time, when feminists in many countries were calling for the liberalisation of abortion laws (SIEGEL, 2014), liberal and feminist voices asserting women's right were deciding whether women wanted to have a child, or not, although decisions were rare at the time (ALBERTYN, 1999, p. 5; COPE, 1993, p. 16; KLAUSEN, 2010, p. 52, 54). In fact, arguments by women's groups were more likely to focus on public health than choice (COPE, 1993).

The law reflected these narratives. Abortion was only available in the absence of choice, either in the sex that preceded pregnancy (rape or incest) or in the health consequences of that pregnancy (serious enough to threaten the life of the mother). Those women were seen as 'morally blameless'. A woman who 'chose' to fall pregnant by having sex outside of marriage, were not eligible for abortions and should 'live with the consequences'. Overall, women were seen with lack of moral authority to act autonomously in their own sexual lives, were left alone to make a decision on abortion, which was decided by male law-makers and medical practitioners. Abortion was limited and regulated with due regard to the interests of doctors, foetuses and conservative morals. Women - and their choices - were incidental to the process (ALBERTYN, 1999, p. 6-7; KLAUSEN, 2010). Black women's choices were even more irrelevant as members of the ruling party, turning it clear that offering abortion 
to 'promiscuous' black women would be an unnecessary drain on state resources (KLAUSEN, 2010, p. 27).

Although, countries such as the United Kingdom, were able to expand access significantly with a similar legal approach based on therapeutic abortion, the restrictive grounds and onerous procedural requirements in South Africa's law placed control firmly in the hands of designated members of the medical staff and the public hospital bureaucracy. The access was limited to women able to secure the support of relevant medical practitioners and negotiate the lengthy, humiliating and costly procedures (BRADFORD, 1991, p. 17-19; COPE, 1993, chs. 11-13; HANSON AND RUSSELL, 1993). Most women terminated their pregnancy on grounds of mental health and about $90 \%$ of abortions took place in two main urban centres and almost half in private clinics (REPRODUCTIVE RIGHTS ALLIANCE, 1996, p. 5). White, middle-class women most likely to access legal abortions, whereas the majority of women were not, especially those who were poor, black, living outside of major urban areas and often young (RRA 1996, p. 5; NGWENA, 1998; SARKIN, 1998). These women often resorted to illegal and unsafe abortions (BRADFORD, 1991, p. 18-21). Indeed, it was estimated that about one in every ten women sought backstreet abortions in the late 1970s (LARSEN, 1978), while a 1989 study reported that nearly half (46\%) of the total admissions in gynaecology at a public hospital in Durban were a result of backstreet abortions (SHWENI et al, 1992).

\section{I.2 Political Transition AND Democracy: LAW REFORM IN THE CONTEXT OF Feminist}

VOICES, PUBLIC HEALTH AND REPRODUCTIVE RIGHTS

Prior to 1990, the dominant narratives in favor of abortion were based on public health. Even liberal voices tended to cite the problems of backstreet abortions to justify abortion on request and a review of the 1975 Act (COPE, 1993, chs. 11 \& 12), while medical practitioners increasingly supported wider access for health reasons (DOMMISSE, 1990, p. 702-3). However, there was little public debate and no public feminist advocacy. For most women, opposition to apartheid took precedence over gender issues and abortion was seen as a divisive topic (BEALL et al, 1989; ALBERTYN, 1999, p. 10-11). Interestingly, for women in the exiled African National Congress (ANC), the conditions of exile served to inform them on issues of reproductive choice. At this point, the burdens of motherhood, gender-based violence and teenage pregnancies, combined with poor health-care, unsafe and illegal abortions, fed the increasing belief by the ANC Women's Section that abortion should be legalised in a democratic South Africa (HASSIM, 2014, chs. 4-5), providing a basis for the development of public health and feminist arguments after 1990.

Between 1990 and 1993, South Africans entered into political negotiations for a democratic constitution. The particular conditions of this political transition enabled claims for gender equality to be inserted in the heart of the new democracy 
(ALBERTYN, 1994; HASSIM, 2006, ch 5). This was possible by an alliance of feminist political activists, academics and lawyers, who were able to rely on feminist activism within the ANC and the political support of a broad constituency of women mobilised to secure inclusion in the new constitution (ALBERTYN, 1999; HASSIM, 2006). This enabling climate also allowed feminist ideas of freedom of choice, equality and reproductive rights to be included on the agenda for the emancipation of women and opened up the possibilities of legal reform on abortion in a democratic South Africa (ALBERTYN, 1999, p. 11-16). In fact, as gender issues became more central to politics in the early $1990 \mathrm{~s}$, various strands of support for a broad pro-choice policy position emerged and women began to organise around reproductive health and rights (ALBERTYN, 1999, p. 11-16; KLUGMAN; VARNEY, 2001). Most importantly, before 1994, women in the ANC persuaded their colleagues that ANC policies relating to the Bill of Rights and health should recognise women's right to choose within an understanding of women's empowerment and their socio-economic circumstances. (ANC, 1992, art 7(2); ANC, 1994, p. 57).

In the transition of the early 1990s, the dominant narratives about the meaning of abortion were based on feminist arguments (equality and choice), public health and reproductive rights. The 'pro-life' arguments, whose public face at that stage was predominantly white, male and rooted in the Catholic Church, were muted by the conditions of constitutional change and women's rights. However, feminist arguments were limited to a relatively small group in the ANC and civil society. In reality, the broad political consensus on gender equality amongst women did not translate into widespread support for abortion on request. In a 1994 national survey, more than two-thirds (68\%) opposed access to legal abortions, whilst a 1995 survey found just under half (45\%) supported the existing law, and only one in five $(21 \%)$ endorsed women's choice (BUDLENDER; EVERATT, 1999). Abortion was contentious, women were perhaps more likely to support the law as it existed, based on medical necessity, than its reform based on feminist arguments and women's rights. Even women who supported law reform were more likely to justify this with public health reasons, than feminist arguments of equality and choice, with consistent reference to the increasing number of deaths and infections of poor, black women from back street abortions (ALBERTYN 1999, p. 17-18).

After democracy, in 1994, feminist and public health arguments put together a relatively small group of health, legal and rights activists and organisations, now mobilised as the Reproductive Rights Alliance, who worked with women in the ANC, in government, to secure progressive reproductive rights frameworks in the final constitution and abortion law reform (ALBERTYN 1999; KLUGMAN; VARNEY 2001). As discussed in the next section, the global shift to reproductive rights and to women's rights as human rights provided an enabling context for a call for abortion law reform as part of a package of rights guaranteed in the South African Constitution. 
Women's rights advocates called on equality and (reproductive) freedom as constitutional imperatives for change, and health activists ensured that a strong public health narrative on backstreet abortions and maternal mortality provided policy justification for legal reform.

Through a combination of advocacy by civil society organisations and pressure by ANC feminists, the final democratic Constitution of 1996 included a guarantee of the 'right to bodily and psychological integrity', including 'the right to make decisions concerning reproduction' and to 'security in and control over their body' in section 12(2), also with the right of access to reproductive health care services in section 27 (ALBERTYN, 1999, p. 26-29). This was in addition to a robust equality right, as well as rights to dignity and privacy, and was one of earliest statements of reproductive rights in a national constitution. In addition, it provided a positive constitutional framework for development of the new abortion law that was slowly making its way through the parliamentary processes under the feminist leadership of both the Minister of Health and chair of the parliamentary portfolio committee. The CTOPA was the first 'women's law' to be passed by the new parliament, largely as a result of enabling political conditions, a positive global and national constitutional framework, committed support by key members of the government and ruling party, as a result of the activism from a small but effective alliance of civil society organisations (rather than widespread public support) (ALBERTYN, 1999, p. 18-26, 30-40; KLUGMAN; VARNEY, 2001).

The CTOPA envisages abortion as the fundamental right of every woman to decide whether or not to have an early, safe, and legal termination of pregnancy, and abortion services are seen as integral to universally accessible reproductive health services, which the state has a duty to provide in an environment that recognizes and respects women's choice (CTOPA, preamble). The CTOPA adopts a trimester approach to permit a woman to terminate a pregnancy during the first 12 weeks of pregnancy upon request and from 13 to 20 weeks with a medical practitioner allowance, after consultation with the woman, and then it is the opinion that the pregnancy poses a risk of injury to the woman's physical or mental health that would matter. There is a risk of severe mental or physical foetal abnormality; or the pregnancy would significantly affect the social and economic circumstances of the woman (CTOPA, section 2(1)(c) \& (b)). ${ }^{2}$ After 20 weeks termination is only permitted if two medical practitioners have the same opinion that the continued pregnancy would endanger the woman's life, resulting in a severely malformed foetus, or putting a risk of injury to the foetus (CTOPA, section 2(1)(c)). ${ }^{3}$ Neither spousal nor parental consent is required (although minors must be advised to consult with her parents or family - section 5). ${ }^{4}$ In the first trimester midwives and nurses, who have undergone training, may perform the abortion (CTOPA, section $2(2))$. The act provides for non-directive and non-mandatory counselling, and the 
obligation to refer patients to designated abortion facilities (CTOPA, section 6), but it is silent on conscientious objection.

On the third part, the implementation of the CTOPA was performed. Before I begin it, I interrogate the nature and scope of the dominant and intersecting public health, rights and feminist narratives identified in this section as justifying the enactment the CTOPA. Using this, I could explore in more detail their limits and contestations, as well as their wider transformative potential.

\section{3 The FEMINIST, Rights-BASED AND PUbliC HEALTH NARRATIVES OF ABORTION LAW REFORM}

The complementary and contested narratives that underpinned abortion law reform in the early 1990s emanated from international norms on the wider issues of reproductive rights and reproductive health, as well as local public health concerns and ideas of women's equality and freedom rights. Thus, we find rights-based arguments that speak to a broad package of reproductive rights (in which abortion is just one aspect), and to women's constitutional rights to equality and freedom of choice, as well as public health arguments that emphasise the health consequences of unsafe abortion and set comprehensive reproductive healthcare for all women. At times these intersect and all are generally driven by feminist concerns of empowering women.

The link between reproductive rights and reproductive health was a major achievement of the International Conference on Population and Development (ICPD) in Cairo in 1994, and it was the idea that reproductive health and rights should be conceptualised in a holistic way, including women's right to control their fertility (CAIRO, 1994; NGWENA, 2010, p. 816). As stated in the Programme of Action (1994, p. 60), reproductive rights were:

[...] rest on the recognition of the basic right of all couples and individuals to decide freely and responsibly the number, spacing and timing of their children and to have the information and means to do so, and the right to attain the highest standard of sexual and reproductive health. It also includes the right of all to make decisions concerning reproduction free of discrimination, coercion and violence as expressed in human rights documents.

Although unsafe abortion was recognised as a major public health problem, the ICPD did not reach a binding commitment on the inclusion of abortion in this definition, and on the need to reform abortion laws so as to address the scourge of abortion-related maternal morbidity and mortality (NGWENA, 201, p.816-7). In the end, the ICPD could not agree that access to a safe and legal abortion was a fundamental right, according to that the state had a duty to provide the services. 
In South Africa in the 1990s, women's health and human rights activists latched upon the spirit of the ICPD's Cairo Declaration to advocate for and achieve a legal right to terminate a pregnancy. While the arguments around the CTOPA occasionally demonstrate a Cairo-like dissonance between public health concerns and abortion rights, they largely show an ability to transcend it. On the one hand, public health discourses were dominant in justifying abortion law reform, and the political emphasis was often on health needs, rather than the wider picture of rights and empowerment. In particular, significant emphasis was placed on the role of abortion in reducing maternal mortality and morbidity, supported by Medical Research Council data on unsafe abortions and deaths (REES, 1997). However, it would be wrong to characterise the narratives on legal reform as solely health-based. On the contrary, in the particular context of South Africa's racialised past, health arguments soon became intertwined with equality and freedom arguments to allow more localised rightsbased narratives to emerge. Although these feminist arguments form part of a global dialogue on abortion rights, and echo feminist narratives elsewhere (see, for example, GREENHOUSE; SIEGEL, 2012), in which they emerge in the particular conditions of the 1990s and have an 'indigenous' South African flavour.

The local feminist, rights-based approaches to abortion can partly be read from the nature and content of South African women's struggles in the late 1980s and 1990s, in which women's emancipation was seen to be inextricably linked to undoing the multiple social, economic and cultural inequalities that perpetuated their subordination (ANC 1990). A strong socialist feminist heritage directed attention to substantive equality, understood as the need to dismantle the structural conditions of women's subordination (ALBERTYN; HASSIM 2003). By 1990, at least some feminists in the ANC and progressive organisations also understood that bodily autonomy and moral agency were essential to women's empowerment (see for example, GINWALA, 1990). Thus, South African discussions on abortion in the 1990s embrace the idea of individual choice and reproductive freedom as being able to control one's body and reproductive capacity, as well as the 'historical and moral' argument based on the 'social position of women and the needs that such a position generates' (PETCHESKY, 1992, p. 2). Whilst the former emphasises women's moral and bodily autonomy, the latter speaks to broad equality issues, including the consequences of unsafe backstreet abortions and the denial of access based on race and class.

Freedom - as reproductive choice - was conceptually and politically less developed that equality in South Africa, as socialist feminist ideas of substantive equality had more historic and political purchase than radical feminist ideas of bodily autonomy (ALBERTYN; HASSIM, 2003, p. 139-143; SEIDMAN, 2003). The political emphasis of women was often on the racial consequences of limited reproductive choice, rather than choice itself. Nevertheless, it was recognised as a central component of reproductive rights, and as described above, was included in the 1996 Constitution in express 
terms. At the core of freedom of choice is the idea of women's moral agency and autonomy. Although, this agreed with the liberal idea of women as autonomous rights-bearers able to make individual decisions about their bodies and lives, for many feminists, the idea of freedom was socially constituted. As Pregs Govender, chair of the parliamentary Committee on the Improvement of the Quality of Life and the Status of Women, stated in the parliamentary debate on the CTOPA:

The right to control our bodies, the right to choose a safe legal termination of pregnancy, is in the context of political, social and economic choices for women, in the context of moving our society towards equality, respect and a healthy sharing of power and responsibility in the home and in society (HANSARD, 29 October 1996, col. 4793).

Overall, however, 'historical and moral' arguments of equality dominated advocacy on abortion, a result of the dominance of equality in the politics of the women's movement and its stated long-term political goals of prioritising the needs of poor, black and disadvantaged women (ALBERTYN; HASSIM, 2003). Legal and women's rights activists in South Africa tended to locate reproductive choice within a wider understanding of substantive equality. ${ }^{5}$ In general terms, this emphasized the multiple inequalities that shaped women's capacity to choose to have sex, fall pregnant, terminate unwanted pregnancies, bear and raise children, on the one hand, and the inequalities that flowed from the legal, social and economic constraints that were placed on these choices, on the other (PETCHESKY, 1990; BIRENBAUM, 1996). In South Africa, during the 1990s, equality arguments focussed particularly on the effects of race and class which placed black, rural and working-class women in the most vulnerable position in relation to reproductive health and choice in general, and access to abortion in particular. In this country, substantive equality required a complex and intersectional understanding of the subordination of women on the basis of gender, race and class.

Equality came to dominate as a political idea and as a strategic choice. In the context of a generally conservative society and an ANC that was, in fact, divided on abortion rights, it was easier to build alliances across groups and argue for abortion rights by portraying the socio-economic realities of poor, black women's lives and the discrimination they suffered under the current law, rather than by asserting women's moral agency and bodily integrity. The racially distorted access to abortion under the 1975 Act meant that black women's lives were most at risk, and the vulnerability and exclusion of this group was a powerful message just after apartheid ended, especially when public face of anti-abortion groups were still dominated by white men, including the fact that South Africa was a socially conservative society with significant opposition to abortion. Indeed, as discussed below, this opposition extended to 
those health-workers who were responsible for providing abortions services (BATEMAN, 2000).

Nevertheless, I want to suggest that the narratives of the early 1990 s also contained an incipient idea of reproductive justice. In response to the individual rights framework of the Cairo Declaration, women of colour in the United States had argued that: 'Our ability to control what happens to our bodies is constantly challenged by poverty, racism, environmental degradation, sexism, homophobia and injustice' (ROSS et al, 2004, p. 4). Women's (lack of) choices are shaped by poverty, (un)employment, ill health, insecurity, (lack of) knowledge and education, violence, infertility, coercion, culture and religion, law. These points are connected to a positive and symbiotic relationship between freedom and equality, and between the nature of one's ability to exercise (reproductive) choice and the broad socio-economic circumstances in which they live. In South Africa, it suggests overcoming the particular exclusion of poor black women from access to abortion under the Apartheid era law, not only required a new law that guaranteed safe access and the provision of comprehensive services, but also attention to the social and economic conditions that impeded meaningful equality and choice.

Nowadays, this idea was not always fully articulated (legally or politically). Once the law was passed, the focus shifted to widening access within a post-apartheid healthcare system through the provision of comprehensive reproductive health-care services. Public and reproductive health narratives again took hold, and feminist ideas of freedom, equality and reproductive justice, while present, were less visible.

\section{TWEnTy yeArs of AbOrtion LAW in South Africa}

The CTOPA was passed in 1996 and implemented soon thereafter in terms of the preamble to the Act which affirmed women's right to reproductive choice and the state's responsibility to provide services to secure this right without fear or harm. Attention shifted to the public and reproductive health imperatives of providing comprehensive services.

Progress in implementation of the CTOPA was initially positive as women were able to access safe, legal terminations, maternal mortality decreasing numbers, and the state, in partnership with civil society, was able to defend the CTOPA against legal and political challenges, provided by a growing and diversifying anti-choice/prolife movement. Despite evidence of significant societal discomfort with abortion and divisions within the ANC over its status, the government and ANC retained a strong, if sometimes rhetorical, commitment to reproductive choice. Over time, however, early problems of implementation expand and become entrenched, affecting the quality and quantity of abortion services, increasing backstreet abortions, and revealing old and new patterns of exclusion. As these problems deepen, there was 
an evidence of a resurgence of civil society activism and emergent state discourses on reproductive justice, in which relocate abortion within wider ideas of empowerment and transformation, and pose possibilities for a renewed emphasis on expanding women's access to reproductive choice.

\section{I A POSITIVE START TO EXPANDING ACCESS AND DEFENDING THE LAW}

At the core of implementing the CTOPA in the mid-1990s, it was government's responsibility to ensure that women could exercise their rights within the overall transformation of the health system and the development of comprehensive maternal, child and women's (MCW) health-care services as a policy priority of the new government. This required a significant redistribution of available resources and structures from a past in which health service delivery was sparse and race-dependent, and where black women in rural, high density urban and peri-urban areas and informal settlements had been particularly disadvantaged. Equity in access to services required the urgent restructuring of the health system as a primary health care system with MCW health care as a key component of the package. An MCW health directorate was established in the Department of Health to coordinate and facilitate the reorganization of MCW health services (HEALTH SYSTEMSTRUST, 1995, p. 181-182). The development of policies focused on institutional transformation and reallocation of resources to deliver effective services, including reproductive health services. The NGO sector weighed in to assist as major national and transnational reproductive health, providing assistance with policy development, training and values clarification. The RRA, which had led the advocacy for the CTOPA, now shifted to supporting implementation. Generally, in the early years 'the nurses and doctors who provided abortions were well-supported and well-regarded' for respecting women's rights (HODES, 2013).

Access expanded rapidly, if unevenly. In a five-year review of the Act in 2002, the state recorded 220888 terminations in the public sector, the majority (73\%) in the first trimester, and 12\% to minors (RRA Barometer, 2002). Although women continued to seek terminations outside the law, there was a significant reduction in maternal morbidity and mortality, especially amongst young women, who had been most at risk in 1994 (JEWKES et al, 2002; JEWKES et al, 2005a). The results of a study commissioned by the Department of Health found the number of patients with high morbidity had almost halved in 2000 (9.5\% in 2000 compared with $16.5 \%$ in 1994). The majority of cases had no signs of infection on admission (90.6\%) and there had been a significant downward trend (from 5.7\% in 1994 to 3.9\% in 2000) in women dying from complications of unsafe abortion. Also, a significant finding was that there had been a $91 \%$ reduction in deaths from unsafe abortion (JEWKES et al, 2002; JEWKES et al, 2005a; IPAS, 2007). Although the decrease in mortality and morbidity became less dramatic over time (BUCHMAN et al, 2008), and these 
earlier studies demonstrated the profound impact of law reform on women's health and lives.

This decrease in maternal mortality and morbidity also provided a rational basis for expanding access in the face of growing anti-choice opposition to the law. Indeed, health and mortality reasons continued to be a major justification for the law and for expanding services.

\section{I. I LEGAL CHALLENGES AND CONFLICTS: DEFENDING WOMEN'S RIGHTS AND}

HEALTH AMIDST A CHANGING PRO-LIFE NARRATIVE

The CTOPA was first tested in court in 1997. In South Africa, the right to abortion was established politically through the legislative process, and it was perhaps less vulnerable to attack than court established rights, such as those in Roe vWade (410 U.S. 113, 1973). However, the first legal challenge aimed at the core of the Act, pitting the right to life of a fetus against the right of women to terminate unwanted pregnancies by claiming that the violation the rights of the fetus was unconstitutional (CHRISTIAN LAWYERS ASSOCIATION V MINISTER OF HEALTH, 1998). This was unsuccessful as the High Court relied on the common law to find that the fetus was not a rights-bearer under the Constitution and could not claim a rights violation (1443 B-C; 1437 C-D). Although, it noted women's constitutional right to reproductive decisionmaking, the court's reasoning sidestepped constitutional arguments, and provided little development of the Constitution's potentially transformative rights framework on reproductive justice (O'SULLIVAN 2008, p. 2-8). However, it effectively prevented future attacks on the Act's basic commitment to choice, meaning that the legal strategies of pro-life advocates shifted from a direct attack on the core right to attempts to narrow the ambit of women's reproductive choice. This also resonated in particular with pro-life strategies in the USA (GREENHOUSE; SIEGEL, 2012).

Attacks on the ambit of choice took a number of forms: challenges to the CTOPA's lack of parental consent provisions for minors seeking abortion and attempts to broaden the ambit of conscientious objection and impose procedural barriers on access to abortion. In relation to the former, the pro-life Christian Lawyers Association challenged the CTOPA provisions permitting minors to obtain an abortion without parental notification or consent (secs $1 ; 5(1)-5(3)$ ) on the basis that minors were incapable of making an informed decision about abortion without parental guidance or control (CHRISTIAN LAWYERS ASSOCIATION V MINISTER OF HEALTH 2005; O'SULLIVAN, 2008, p. 18-21). The Christian Lawyers Association argued that, by excluding parental consent, the CTOPA violated the minor's rights to family and parental care, to equal protection and the constitutional requirement that a law was in 'the best interests of the child' (CONSTITUTION, 1996, secs 28, 9). This argument denied moral autonomy to minors to make reproductive decisions. The High Court found that the CTOPA's requirement of informed consent was constitutional as 'valid 
consent can only be given by someone with the intellectual and emotional capacity for the required knowledge, appreciation and consent' (p. 515). Minors were capable of this, they could consent; the test for informed consent was not about the age, but capacity to consent (p. 516-517). Again the attempt to undermine the moral autonomy of women (in this case, minors) was unsuccessful. However, this choice remained legally entrenched (O’SULLIVAN, 2008).

Finally, in 2004, the Department of Health tabled legislation amending the CTOPA in Parliament to increase access to safe termination of pregnancy services and achieve better governance of those services. ${ }^{6}$ Provincial public hearings on the amendments became a site of struggle over women's rights to abortion as pro-life groups used the opportunity to propose significant procedural obstacles to procuring an abortion (for example, SMYTHE, undated). For the first time, the public face of the anti-abortion lobby was not that of white, professional men, but of large numbers of black, church-going township women and men (RRA 2007). The emergence of this more widespread public opposition was due to a number of factors, including the rise of pentecostal churches in South Africa connected to US evangelism (CHIPKIN; LEATT, 2011, p. 22). In the end, all nine provinces supported the Bill $^{7}$, which duly passed through Parliament. In leading the vote in favour of the Bill in the National Assembly, Chair of the Health Portfolio Committee, ANC member James Ncgulu confirmed that 'women must be given choice to determine about their reproductive rights' ${ }^{8}$ This outcome was possible because of organised civil society advocacy in favour of the CTOPA amendments and the ruling party's commitment to, and positive leadership on, reproductive choice in both the relevant national and provincial parliamentary committees and the Health Ministry.

It is worth pausing to comment on the shifts in public narratives on abortion rights that these events signify. Firstly, the pro-life narratives had shifted and diversified from the 1990s. Members of religious and church groups continued to censure women who procured abortions as murderers of unborn children. In addition, this found different forms, most visibly in the moral censure of women who aborted foetuses outside the law or, in the desperation of poverty 'dumped, newly born babies (FARBER, 2012). However, to counter the women's rights arguments, some 'pro-life' advocacy organizations, such as Doctors for Life, began to focus on the harm caused to women by abortion (RRA 2007). Drawing directly on US pro-life arguments, these suggested that abortion resulted in damaging physical and, especially, psychological consequences for women, which was called for more rigid procedures to 'protect' women. These included mandatory counselling, including photographic images; wider provision for conscientious objection; parental consent for minors; and limiting the numbers of service providers and facilities for terminations (see for example, SMYTHE, undated). Underlying these was a paternalistic idea of women as 'victims' of abortion requiring help in making the 'right' moral choice. 
In contrast, women's health and rights groups asserted reproductive choice as an unassailable right, reminding the members of parliament who attended the hearings of the importance of the CTOPA to women's health and well-being. In addition, public health and equality arguments dominated as these groups drew on research that showed how the legalization of abortion had significantly reduced maternal morbidity and mortality, but that many poor, rural and unemployed women were still unable to access safe, legal abortions. The amendments, it was argued, were critical to extending the right to all women by improving the reach and quality of termination of pregnancy services. While feminist arguments concerning choice were also central, these were always linked to the socio-economic conditions and consequences of women's actual (in)ability to exercise reproductive choice. ${ }^{9}$ To some extent, the hearings confirmed that the abortion debate was shifting from an exclusive focus on women's rights versus foetal rights to competing claims as to what is in the best interests of women (already apparent in the second Christian Lawyers Association case). This example brings into sharp focus the contesting ideas of women that characterise each side. On one side, those opposing abortion speak of protecting women, suggesting women require more information and assistance in making choices about abortion and that the law should be amended to reflect this. The anti-abortion focus of these arguments means that there is a normative and practical bias against choice. Women are seen as mothers, victims or promiscuous agents - in all instances these views suppress the agency of women and show little understanding of their context. On the other side, the promotion of reproductive choice is asserted in the context of women's lives. Thus, it is recognized that women live in a societal context in which their rights and freedoms are limited by gendered power and inequalities, reflected in discriminatory attitudes, beliefs and practices. These rights arguments generally seek to affirm women's agency, whilst understanding the social and economic context that constrains this.

The right to choose an abortion and also the ideas of women that underpin this law remained sites of struggle as the state and civil society organisations have sought to defend the CTOPA in the past two decades. However, recently there has been evidence of a growing conservatism within the state, a demobilisation in civil society and a decline in the provision of abortion services that has raised new concerns about how to protect and expand women's access to reproductive health-services, especially for poor women. This is discussed in the next section.

\subsection{DeEPEning Inequalities of ACCess}

Since the regulation of the CTOPA, an increasing numbers of women have obtained safe, legal abortions in public hospitals, from 26455 in 1997 to 82920 in 2012 (HEALTH SYSTEMS TRUST, undated). Every year, further than 40000 women or so obtain abortions from just one private clinic with outlets across the country (HODES, 
2013). On the opposite side, it is estimated that at least the same number of women seek illegal abortions (HODES, 2013). The reasons for this are complex, and relate to the nature and availability of legal and illegal services, as well as women's knowledge about the law and their willingness and ability to access the public health system.

Despite the good news on maternal health, the review of the first five-year of the CTOPA provided early signs that old patterns of exclusion had not been fully addressed. While poor and young women enjoyed more access, this was not true of those living outside major urban centres and in rural provinces. In addition, difficulties were experienced in providing sufficient service-providers for second trimester abortions (RRA Barometer, 2002). Women were still turning to illegal abortion providers, but the dramatic declines in maternal mortality and morbidity, especially for young women (JEWKES et al, 2005) suggested that the backstreet had become less unsafe (BROWN, 2000, p. 6-7).

Recently, the evidence suggests that the right to a safe legal abortion in South Africa - especially for poor, black and rural women - has diminished. Research suggest that women are accessing terminations, but in circumstances in which the official statistics reflect state capacity, rather than real demand. Indeed, in 2013, less than $40 \%$ of designated abortion facilities were operational (TRUEMAN; MAGWENTSHU, 2013). Healthcare workers provide the service under difficult circumstances, in over-crowded and under-resourced facilities, with little support and in the face of hostile attitudes from peers and superiors (MAYERS et al, 2005; HARRIES et al, 2009; MAMABOLO; TJALLUKS, 2010). In addition, many women face systematic and multi-faceted stigmatisation, not only from health-care workers, but also from administrative and cleaning staff (BATEMAN, 2011; HARRIES et al 2009; ORNER et al, 2010; JEWKES et al, 2005). Young women often find themselves being chastised for being irresponsible (HODES, 2013) - as do sex workers, LBTI, disabled, foreign nationals and HIV positive women (SHARISA, 2015). The decline in services has been significantly affected by health-worker 'burn-out' and conscientious objection. South Africa is a strongly traditional and religious country, ${ }^{10}$ with widespread opposition to abortion based on religious beliefs. In fact, health workers themselves have generally opposed the CTOPA. One study reported that $64 \%$ of members of the Democratic Nurses Association of South Africa opposed the CTOPA (BATEMAN, 2000), and another found that only 56\% of those assisting in abortions found 'abortion on request' to be morally acceptable (VARKEY; FONN, 1999). In the public health system, this expresses itself as hostile or aggressive behaviour, as a refusal to take part in abortion services (BATEMAN, 2000), or, for managers, a reason to 'act as gatekeepers [and to] ... prevent services from being provided in the facilities they manage' (TRUEMAN; MAGWENTSHU, 2013, p. 398). The unregulated nature of conscientious objection, with little guidance offered by policy makers, has seen 'conscientious objection becoming one of the biggest barriers 
to abortion service delivery' (TRUEMAN; MAGWENTSHU, p. 398. See also HARRIES et al, 2014).

Underlying these problems are a number of issues related to the health system as a whole. It is doubtless correct that the reform of the health system after apartheid provided the opportunity to begin the development of a comprehensive reproductive health-care services, including abortion services. However, the enormity of this task, together with the fact that the health system has suffered enormous strain under the weight of the HIV epidemic, has also counted against the development of quality services. As a 2009 Report on the South African healthcare system noted:

Although restructuring of the public health sector post 1994 achieved substantial improvements in terms of access, rationalisation of health management and more equitable health expenditure, fifteen years later these early gains have been eroded by a greatly increased burden of disease related to HIV/AIDS, generally weak health systems management and low staff morale. The result is poor health outcomes relative to total health expenditure (HARRISON, 2009).

As early as 1998, women's health researchers pointed to problems with service delivery that were likely to become entrenched within a public health system (FONN et al, 1998). In relation to abortion on the late 2000s, researchers were acknowledging pockets of excellence and dedicated service, but also a poor and declining infrastructure, associated with a decrease of facilities and service providers, especially in the second trimester where a medical doctor is required. They conclude that women seeking abortions experience delays, incorrect referrals, long waiting periods (often pushing them beyond first or even second trimester limits), rejection, stigmatization and poor quality of care (JEWKES et al, 2005; ORNER et al, 2010, HARRIES et al, 2009). It is clear that solving these problems is not just a matter of better reproductive healthcare services, but linked to South Africa's ability to address the problems within the heath-care system as a whole.

In this context, women often choose the backstreet. Some do so because they are not aware that abortion is legal. In one study, at least $30 \%$ of respondents believed that abortion was still illegal (WHO, 2008). Others consciously choose what is seen to be a quicker and more private route than the queues, delay and hostility of the public sector. Although the evidence is anecdotal or based on small-scale research, it is clear that the availability of 'abortion pills' on the black market, such as Cytotec and Misoprostal, has expanded access to illegal abortion (MOORE; ELLIS, 2012; JEWKES et al, 2005b; HARRIES et al, 2015). In general, as Jewkes et al note, women often prefer a quick and private response to unwanted pregnancies and seek 'backstreet' assistance in which safety varies, but where self-induced methods are most 
likely to lead to ill-health, infertility and death (2005b). Research in Kenya, albeit in a more constrained legal environment, has similarly shown that women seek the privacy of backstreet abortions, and claim that these are 'key to women's preservation of a good self, management of stigma, and protection of their reputation, respect, social relationships and livelihoods' (IZUGBARA et al, 2015, p. 9).

\subsection{DeClining POlitical Will AND NeW DiRections}

One key lesson of the 1990s and early 2000s was the critical role that strong political leadership and civil society activism played in making, shaping and implementing the law. South Africa has never been a country which the majority of people support abortion on demand. Only about one third to one quarter do so in any given survey, although more support abortion under restricted circumstances (BUDLENDER; EVERATT, 1999). However, political leaders were always willing to speak to the ANC's commitment to safe abortion, especially for poor, black women. Despite a growing anti-choice opposition and continuing divisions within the ANC over abortion, the support of the state was remarkably consistent, suggesting that gender equality and women's human rights remained an important measure of democratic progress for the government. Perhaps significant here was the ability of women's organisations to present themselves as a political constituency to whom the state felt accountable (such as the parliamentary portfolio committee on Health in the 2007 hearings). Such accountability is, in part, due to the ability of these organisations to present a united front and a coherent vision of women's autonomy and gender equality, rooted in evidence of the law's positive impact on women's lives. It is also due to women's health advocates sustaining relationships with parliamentarians, members of government, departmental officials and service providers over the year.

In recent years, this appears to have changed. On one hand the broad-based unity and the movable power of an 'abortion constituency' signified by the RRA has been less visible with the decline of the RRA as a national voice around 2011. The ability of civil society to work alongside government has also been affected by the departure of key transnational NGOs (IPAS, 2014). On the other hand, a wider discourse of 'moral regeneration' and 'traditional values' under President Zuma has meant limited state support for women's rights and gender equality issues. This has also manifest itself in a reclaiming of patriarchal values in culture and custom, and a strengthening of the traditional roles of women as wives and mothers, and subordinate to men in public and ANC discourse (SUTTNER, 2010, p. 22-27). Needless to say, it has diminished the public space for discussions about the need for abortion. Indeed, civil society activists argue that government is much less willing to talk about and defend women's rights, and also even less willing to defend abortion than in previous years (HODES, 2013). 
Whilst not directly opposing the CTOPA, it appears to be a little normative and practical commitment to safe, legal abortion in the Ministry of Health (STEVENS, 2014; TRUEMAN; MAGWENTSHU, 2013). The Minister of Health is more likely to express disapproval of young girls using abortion as contraception (with no data to prove this claim), than discuss the difficult social and economic circumstances that influence young women's choices about sex (HODES, 2013). These issues, coupled with unregulated conscientious objection, indicate that state apathy and declining political will have eroded the ruling party's prior commitment to women's reproductive rights.

Although the balance of forces within the ANC appears to have shifted to a more conservative approach to abortion, there are a few encouraging signs with the re-emergence of strong feminist voices. Minister of Social Development, Bathabile Dlamini, recently argued that the provision of abortion services is essential to 'the transformation of society that enables the complete emancipation of women' (DLAMINI, 2014). She called for commitment to reproductive justice: 'where all people [and especially the poor and the marginalised] have the social, political and economic power and resources to make healthy decisions about their gender, bodies and sexualities' (DLAMINI, 2014). In doing so, she drew a clear connection between the commitments of the early 1990s to addressing the exclusion of black women from safe, legal termination of pregnancy, to the needs of the present: 'It is vital for us to be true to the intention of the ANC in 1995 for access to quality abortion services by poor women as part of its social justice and transformation goals' (DLAMINI, 2014).

Anecdotal evidence suggests that the call to reproductive justice is a shrewd one, as it links reproductive choice to key social and economic concerns:

Within the framework of reproductive justice, the ANC and the ANC government has always been and will always be pro-abortion in the sense that we realise that it is but one of the reproductive experiences of women that needs to be enabled. We are also concerned about improving other elements of women's reproductive experiences such as improving women's economic and educational statuses, we are concerned about whether women are in violent or abusive situations, whether their children have access to nutritious food, housing, clothing and other social protection services (DLAMINI, 2014).

By referring to marginalised communities, by bringing in the economy and poverty, and by demonstrating that the ability to choose is integrally linked to one's social and economic conditions, abortion can be seen as part of the ANC's re-commitment to 'radical socio-economic transformation' (ZUMA, 2015). If democracy and transformation provided the political space for abortion and reproductive rights to 
be advanced in the early 1990s, the question is: whether there are similar opportunities twenty years to advance women's access to abortion and the implementation of the CTOPA under the frame of reproductive justice? This is discussed in the final section.

\section{Abortion law at the Cross-roads? Lessons and Challenges}

South Africa is at a cross-roads concerning its willingness and capacity to implement its progressive abortion law. It can limp along as it is, paying lip-service to women's rights to safe abortion, but in fact deferring to a more conservative set of norms and narratives about women's abortion rights; or it can commit to providing comprehensive, safe, confidential and supportive services to all women, recognising that the Constitution affirms that choice to have an abortion is a right of all women. At present, the gap between rich and poor in access to healthcare in general, and reproductive healthcare in particular, is significant. Women with means access private services. Poor women rely on the state or illegal providers, to the detriment of their health and lives. Whilst the provision of safe, legal abortion in 2015 remains an advance on the limited and discriminatory provision of abortion under apartheid, the early gains of the 1990s have been eroded and the state has failed to progressively realise women's right of access to reproductive health-care in general and safe abortion in particular.

If we return to the lessons of the 1990s discussed above, we know that the ability to reconceptualise women's rights and to advance them in law and practice depends on at least four things: (i) Political conditions that enable change (a moment of transition of some kind or another); (ii) political leadership which is supportive of gender equality (often persuaded to do so by shrewd feminists and gender activists within the party and the state); (iii) a conceptual framework that allows feminist and women's rights claims to be made (such as a rights-based constitution) and (iv) a mobilised women's movement. Is it possible that the conditions for substantive change might be emerging, in a different way, in South Africa? I finish this article on an optimistic note by speculating on that possibility.

First of all, in respect of defining a moment of change, if not transition, it is worth asking whether South Africa does not face a second cross-roads? In the face of increasing economic inequalities and growing unemployment rates, growing social conservatism, high levels of corruption and disintegrating public services, the social compact of the early 1990s is certainly fraying at the edges. In his state of the nation address this year, President Zuma called for more radical social and, especially economic, transformation (ZUMA, 2015). Also, there was little meaningful content to his call, it does signify a recognition that things cannot stay the same in South Africa. If this does, in fact, lead to a moment of change, a re-commitment of the constitutional agreement of the 
1990s to include not only those subordinated by race and gender (as was the core commitment of 1993), but also those excluded by class and economic injustice, and then it would provide an second moment of 'transition'. (What some refer to an economic transition). As suggested above, the idea of 'radical socio-economic transformation' might enable feminists and gender activists, within the state and in civil society, to insert new claims for reproductive justice in policies, laws and modes of implementation and enforcement of those policies and laws.

Second, it is difficult to discern shifts in political leadership, although the increasingly visible role of minister Dlamini in South Africa and on the continent suggests that spaces are opening up for more progressive and feminist voices. Dlamini's strong defence of reproductive justice certainly provides an opportunity to develop it as a conceptual framework, but more feminist political voices will be needed for this to signify a meaningful shift.

Third, the progressive understanding of abortion as essential to women's freedom and equality has lost public traction (especially as it relied on the apartheid past). Can a development of the idea of reproductive justice enable a re-articulation of these rights in ways that resonate with present needs and allow civil society to hold government to account for the effective implementation of the CTOPA? Complex inequalities have always structured women's choices. In 2015, the link between reproductive choice and substantive equality - in the sense of a meaningful redistribution of power and resources - are perhaps more overt than they were in 1994. The problem is not merely the absence of abortion services, it is also the social and economic circumstances of women's lives, and the structures and institutions of a patriarchal society, that affect all aspects of their lives. These choices are implicated by local, national and global conditions. As noted by Dlamini above, such an understanding of abortion enables stronger social and economic justification for ensuring that women are able to exercise meaningful choices, including access to safe and legal abortion.

Finally, the mobilisation of civil society was critical to progress in the 1990s, as it is now. As Minister Dlamini notes:

Without the broad women's movement being concerned with advocating for abortion rights and access to abortion services as part of the broader women's struggles for economic equality, social justice and violence against women, what we call 'choice' may just become an elitist individualised response to reproductive rights which would still be mainly, for the middle classes and the rich (2014).

The struggle for reproductive justice should be linked to wider struggles against poverty and inequality, against conservative notions of women in tradition, religion and culture, against gender-based violence and so on. At this point, recent attempts 
to rebuild a constituency of organisations based on sexual, reproductive rights, and reproductive justice, is a hopeful sign (SHARISA, 2015).

In many ways, the South African experience resonates with that comparing to other countries. However, what been particularly important for progress in South Africa has been the fact of democratic transformation, enabling normative and systemic change in the rights, values and narratives surrounding abortion, as well as the healthcare system that provides the services. It is a significant factor that has been the political will expressed by crucial actors in the ANC during the transition and well into democracy. As the transition recedes into the past, and as the South African healthcare system declines and political will seems to waver, new possibilities emerge for meaningful change. The present challenge for those seeking a better life for women is to exploit the spaces and opportunities that now exist. In this respect, despite the ebb and flow of support for, and opposition to, abortion, the fact of clear constitutional and legal rights provides an enduring basis for pursuing reproductive justice, including attainable abortion rights.

NOTES

1 Section 3 of Act 2 of 1975 permitted abortion in the following circumstances:

(a) where the continued pregnancy endangers the life of the woman concerned or constitutes a serious threat to her physical health, and two other medical practitioners have certified in writing that the continued pregnancy so endangers the life of the woman concerned or so constitutes a serious threat to her physical health and abortion is necessary to ensure the life or physical health of the woman;

(b) where the continued pregnancy constitutes a serious threat to the mental health of the woman concerned and two other medical practitioners have certified in writing (one of whom is a registered ... psychiatrist) that the continued pregnancy creates the danger of permanent damage to the woman's mental health and abortion is necessary to ensure the mental health of the woman;

(c) where there exists a serious risk that the child to be born will suffer from a physical or mental defect of such a nature that he will be irreparably seriously handicapped, and two other medical practitioners have certified in writing that there exists on scientific grounds, such a risk;

(d) where the fetus is alleged to have been conceived in consequence of unlawful carnal intercourse (rape or incest) and two other medical practitioners as well as a magistrate are satisfied that the rape occurred; or

(e) where the fetus is alleged to have been conceived in consequence of illegitimate carnal intercourse (with a mentally disabled woman) and it is certified that she is unable to understand the implications of the act and bear parental responsibility.

2 2. (1) A pregnancy may be terminated-

(a) upon request of a woman during the first 12 weeks of the gestation period of her pregnancy; 
(b) from the 13th up to and including the 20th week of the gestation period if a medical practitioner, after consultation with the pregnant woman, is of the opinion that-

(i) the continued pregnancy would pose a risk of injury to the woman's physical or mental health; or

(ii) there exists a substantial risk that the fetus would suffer from a severe physical or mental abnormality; or

(iii) the pregnancy resulted from rape or incest; or

(iv) the continued pregnancy would significantly affect the social or economic circumstances of the woman ...

3 2. (1) A pregnancy may be terminated- ...

(c) after the 20th week of the gestation period if a medical practitioner, after consultation with another medical practitioner or a registered midwife, is of the opinion that the continued pregnancy-

(i) would endanger the woman's life;

(ii) would result in a severe malformation of the fetus; or

(iii) would pose a risk of injury to the fetus.

4 5. (1) Subject to the provisions of subsections (4) and (5), the termination of a pregnancy may only take place with the informed consent of the pregnant woman.

(2) Notwithstanding any other law or the common law, but subject to the provisions of subsections (4) and (5), no consent other than that of the pregnant woman shall be required for the termination of a pregnancy.

(3) In the case of a pregnant minor, a medical practitioner or a registered midwife, as the case may be, shall advise such minor to consult with her parents, guardian, family members or friends before the pregnancy is terminated: Provided that the termination of the pregnancy shall not be denied because such minor chooses not to consult them.

5 For an example of the argument that reproductive rights are a fundamental prerequisite to ensure substantive equality for women in our society, see Ex Parte: the Constitutional Assembly In re: The Application to Certify a new Constitution in terms of Section 71 of the Constitution of the Republic of South Africa, 1993. Submission of the Reproductive Rights Alliance in re: sections 12(2)(a) and (b) and 27(1)(a) and Ex Parte: the Constitutional Assembly In re: The Application to Certify a new Constitution in terms of Section 71 of the Constitution of the Republic of South Africa, 1993. Heads of Argument, July 1996.

6 The Choice on Termination of Pregnancy Amendment Act, 38 of 2004, inter alia, sought to speed up the process of designating abortion facilities; increase the pool of trained providers; and improve the monitoring of TOP services through collection of statistics and information.

7 Social Services Committee, National Council of Provinces, Choice on Termination of Pregnancy $A / B$ and Traditional Health Practitioners Bill [B20-2007]: Final Deliberations 18 September 2007. It was noted that most of the objections spoke to the main act, not the amending act.

8 Proceedings of the National Assembly, Thursday $13^{\text {th }}$ January 2008.

9 Submissions of Centre For Applied Legal Studies, University of The Witwatersrand 'Submission To The Gauteng Provincial Hearings on The Choice On Termination Of Pregnancy Amendment Act, Act 38 of 2004' (n.d.); Reproductive Rights Alliance 'Submission To The Gauteng Provincial Hearings on The Choice On Termination Of Pregnancy Amendment Act, Act 38 Of 2004' (n.d) (on file with author).

$1080 \%$ of South Africans refer to themselves as Christian. South African Government Information. Statistics South Africa. South African Census, 2011. 


\section{REFERENCES}

ALBERTYN, Catherine. "Women and the transition to democracy in South Africa". Acta Juridica. 1994, p. 39-63.

"Reproductive Health and the Right to Choose: Policy and Law Reform on Abortion". In

ALBERTYN, C. (ed.) Engendering the Political Agenda (1999), chapter 3, Centre for Applied Legal Studies: Johannesburg.

; HASSIM, Shireen. “The Boundaries of Democracy: Gender HIV/AIDS and Culture”. In: Everatt,

D.; Maphai, V. The Real State of the Nation (2003) Interfund: Johannesburg.

; MEER, Shamim. “'Citizens or Mothers' The Marginalisation of Women's Reproductive Rights in

the struggle for access to reproductive health-care for HIV-positive pregnant women in South Africa”. In: Gender, Rights and Development: A Global Source Book. (2008), KIT; OXFAM GB: The Netherlands.

BATEMAN, Chris. "Abortion practices undermining reformist laws" South African Medical Journal. Vol. 101, 2011, 302-304.

BEALL, Jo; HASSIM, Shireen; TODES, Alison. “'A bit on the side’?: Gender struggles in the politics of transformation in South Africa. Transformation 1989. Vol 21, p. 301-310.

BIRENBAUM, Joanne. "Abortion, Equality and Decisions concerning Reproduction”. South African Journal on Human Rights. Vol. 19, 1996, p. 485-503.

BRADFORD, Helen. "Her Body, her life: 150 years of abortion in South Africa". Unpublished conference paper 'Women and Gender in Southern Africa' University of Natal, Durban, 1991.

BUDLENDER, Debbie; EVERATT, David. "How Many For and How Many Against? Private and Public Opinion on Abortion”. Agenda. Vol. 40, 1999, p. 101-105.

CHIPKIN, Ivor; LEATT, Annie, "Religion and Revival in Post-Apartheid South Africa". Focus. Vol. 62, 2011, p. $39-46$.

COPE, June. A Matter of Choice: Abortion Law Reform in Apartheid South Africa. Pietermarizburg: Hadeda Books, 1993. DOMMISSE, G. "Current Attitudes of Members of SASOG to the Present Law on Abortion" South African Medical Journal. Vol. 74, 1990, p. 702-707.

FONN, Sharon; XABA, Makosazana; TINT, Kin San; CONCO, Daphne; VARKEY, Sanjani. "Reproductive Health Services in South |Africa: From Rhetoric to implementation”. Reproductive Health Matters. Vol. 6, 1998, p. 22-32.

GREENHOUSE, Linda; SIEGEL, Riva. B. Before Roe v. Wade. Voices that shaped the abortion debate before the Supreme Court's ruling. New Haven: Yale Law School.

HARRIES, Jane; LINCE, Naomi; CONSTANT, Debbie; HARGAY, A; GROSSMAN, Daniel. "The Challenges of offering second trimester abortion services in South Africa: Healthcare providers perspectives”. Journal of Biosocial Science. Vol. 44, 2012, p. 197-208.

; STINSON, Kathryn; ORNER, Phyllis. "Healthcare providers' attitudes towards termination of pregnancy: A qualitative study in South Africa”. British Journal of Obstetrics and Gynaecology. Vol. 9, 2009, p. 296. ; COOPER, Diane; STREBEL, Anna; COLVIN, Christopher "Conscientious Objection and its impact on abortion service provision in South Africa: A qualitative study". Reproductive Health. Vol. 11, part 16, 2014 , p. $1-7$.

; GERDTS, Caitlin; MOMBERG, Mariette; GREENE FOSTER, Diana. “An exploratory study of what happens to women who are denied abortions in Cape Town, South Africa" Reproductive Health.

Published online 2015 Mar 21. doi: 10.1186/s12978-015-0014-y

http: / /www.ncbi.nlm.nih.gov/pmc/articles/PMC4371847/

HARRISON, David. "An Overview of Health and Health care in South Africa 1994 - 2010: Priorities, Progress and Prospects for New Gains”. A Discussion Document Commissioned by the Henry J. Kaiser Family Foundation to Help Inform the National Health Leaders' Retreat, Muldersdrift, January 24262010 HANSSON, Desirée; RUSSELl, Diana E.H. "Made to Fail: The Mythical Option of Legal Abortion for Survivors of Rape and Incest" South African Journal on Human Rights 1993, Vol. 9, p. 500-524.

IZUGBARA, Chimaroake O., EGESA, Carolyne; OKELO, Rispah. "'High Profile health facilities can add to you trouble': Women, stigma and un/safe abortion in Kenya” Social Science and Medicine. Vol. 141, 2015, p. 9-18.

JEWKES, Rachel; BROWN, Helen; DICKSON-TETTEH, Kim; LEVIN, Jonathan; REES, Helen. "Prevalence of morbidity associated with abortion before and after legalisation in South Africa". British Medical Journal. Vol. 324, 2002, p. 1252-1253.

; REES, Helen; DICKSON, Kim; BROWN Heather; LEVIN Jonathan. "The impact of age on the epidemiology of incomplete abortions in South Africa after legislative change". International Journal of Obstetrics and Gynaecology. Vol. 122, March 2005a, p. 355-359. 
; GUMEDE, T.; WESTAWAY, M. S.; DICKSON, Kim; BROWN, Helen; REES, Helen. "Why are women still aborting outside designated facilities in Metropolitan South Africa”. Britsih Journal of Obstetrics and Gynaecology. Vol. 12, 2005b, p.1236-1242.

KLAUSEN, Suzanne M. “'Reclaiming the White Daughters' Purity'. Afrikaner Nationalism, Racialised Sexuality and the 1975 Abortion and Sterilisation Act in Apartheid South Africa”. Journal of Women's History. Vol. 22, 2010, p. 39 63.

KLUGMAN, Barbara; VARNEY, Sanjani. "From policy development to policy implementation: The South African Choice on Termination of Pregnancy Act”. In: KLUGMAN, Barbara; BUDLENDER, Debbie (eds.), Advocating for abortion access: Eleven country studies. (2001) The Johannesburg initiative, Women's Health Project, School of Public Health, University of the Witwatersrand.

LARSEN, L. "Induced Abortion”. South African Medical Journal. Vol. 53, 1978, p. 853-854.

MAMABOLO, L.; TJALLINKS, J. "Experiences of registered nurses in one community health centre near Pretoria providing termination of pregnancy services". African Journal of Nursing and Midwifery Vol. 12, 2010, p. 73-86.

MYERS, Pat; PARKS, Briony; GREEN, Beryl; TURNER, Judy. "Experiences of Registered midwives assisting with termination of pregnancies at a tertiary level hospital'. HealthSA Vol. 10, 2005, p. 15-25.

NGWENA, Charles. "The History and Transformation of Abortion Law in South Africa". Acta Academia 1998, p. 32 68 .

. "An Appraisal of Abortion Law in Southern Africa”. International; Comparative Health Law and Ethics. Vol. 32, 2004, p. 708-717.

"Inscribing abortion as a Human Right: Significance of the Protocol on the Rights of Women in Africa". Human Rights Quarterly. Vol. 32, 2011, 783-864.

ORNER, Phyllis; DE BRUYN, Maria; HARRIES, Jane; COOPER, Di. "A qualitative exploration of HIV positive pregnant women's decision-making regarding abortion in Cape Town, South Africa”. Journal of Social Aspects of HIV/AIDS. Vol. 7, 2010, p. 44-51.

O'SULlivan, Michelle. "Reproductive Rights". In: WOOLMAN, Stu; BISHOP, Michael. Constitutional Law of South Africa. 2. ed. Juta and Co: Cape Town, 2008.

PETCHESKY, Rosalind. Abortion and Women's Choice. The state, sexuality and reproductive freedom. Boston: Northeastern University Press, 1993.

PICKLES, Camilla. "Lived Experiences of the Choice on Termination of Pregnancy Act 92 od 1996". South African Journal on Human Rights. Vol. 29, 2013, p. 515-535.

REES, Helen. 'Public Health and Reproductive Rights' RRA 2002, p. 15-17.

REES, Helen et al. "The epidemiology of incomplete abortion in South Africa". South African Medical Journal. Vol. 87, 1997 p. 432-437.

SARKIN, Jeremy. "Patriarchy and Discrimination in Apartheid South Africa's Abortion Law". Buffalo Human Rights Law Journal. Vol. 41, 1998, p. 69-82.

SEIDMAN, Gay. "Institutional Dilemmas. Representation versus Mobilization in the South African Gender Commission”. Feminist Studies Vol. 29, 2003, p. 541-563.

SHWENI, PM. MARGOLIS, J.; MONOKOANE, TS. 'Abortions: the King Edward VIII hospital experience”. $O$ \& $G$ Forum Vol. 2:2, July 1992, p. 27-33

SIEGEL, Riva 'The Constitutionalization of Abortion' in COOK, Rebecca. ERDMAN, Joanna; DICKENS, Bernard. Abortion Law in Transnational Perspective: Cases and Controversies. Philadelphia: University of Pennsylvania Press, 2014. SILLIMAN, Jael, GERBER FRIED, Marlene, ROSS, Loretta, GUTIERREZ, Elena R. Undivided Rights. Women of Colour organise for Reproductive Justice Ross. South End Press, 2004.

SUTTNER, Raymond. 'Crisis of South Afrucan Liberation. In and Beyond the Zuma Era' Studies on Political Parties and Democracy, edited by the Friedrich Ebert Stiftung, Mozambique. 2010, <http://s3.amazonaws.com/ academia.edu.documents/31122584/ANC_STUDY_-_FES_2010_review2.pdf?AWSAccessKeyId= AKIAJ56TQJRTWSMTNPEA\&Expires $=1438882896 \&$ Signature $=\% 2 B P O B 8 p f 7$ tonouGSSL2KRDE5yp $\% 2$ FM $\% 3$ D\& response-content-disposition=inline $>$ accessed 6 August 2015.

TRUEMAN, Karen; MAWENTSHU, Makgoale. "Abortion in a progressive legal environment: The need for vigilance in protecting and promoting acees to safe aortion services in South Africa". American Journal on Public Health. Vol. 103, March 2013, p. 397-399.

VARKEY, Sanjani; FONN, Sharon. “Termination of Pregnancy”. South African Health Review. 1999, p. 357-368.

\section{Other literature}

African National Congress. A National Health Plan for South Africa, 1994. 'Ready to Govern: ANC Policy Guidelines for Democratic South Africa'. 1992.

<http:/ / www.anc.org.za/show.php?id=227> accessed 25 July 2015. 
. Constitutional Committee. A Bill of Rights for South Africa. May 1992.

Women's League "Health Sector. Gender Empowerment for radical socio-economic transformation". 2015. Policy document. <http://www.anc.org.za/docs/discus/2014/healthx.pdf>Accessed 5 August 2015. BROWN, Heather. "The National Incomplete Abortion Study. South Africa 2000” in Reproductive Rights Alliance Barometer 2000.

DLAMINI, Babathile. "The ANC's approach to abortion" speech at the opening of the Reproductive Health Rights Conference, 10 June 2014. <http://www.politicsweb.co.za/documents/the-ancs-approach-toabortion-bathabile-dlamini>. Accessed 25 July 2015.

FARBER, Tanya. "Baby dumping on the rise in W Cape". IOL online, March 312012.

<http://www.iol.co.za/news/south-africa/western-cape/baby-dumping-on-the-rise-in-w-cape-

1.1267814\#.VjcrK6MaL4Y>.

HEALTH SYSTEMS TRUST. South African Health Review. 1995, Health Systems Trust and Henry J Kaiser Foundation. . 'TOPs (Terminations of Pregnancy)'. Undated, <http://indicators.hst.org.za/healthstats/47/ data $>$. Accessed 25 July 2015.

HODES, Rebecca. 'Abortion in South Africa: a conspiracy of silence' Daily Maverick, South Africa. <http://www.dailymaverick.co.za/article/2013-09-30-abortion-in-south-africa-a-conspiracy-ofsilence/\#.VcGz5qMaL4Y>. Accessed 1 August 2015.

MOORE, Jina; ELLIS, Estelle. “In South Africa, a Liberal Abortion Law Doesn't Guarantee Access”. $<$ http:/ / pulitzercenter.org/south-africa-illegal-liberal-abortion-law-access-guarantee-rights-reproductivehealth>. Accessed 25 July 2015.

IPAS. "Submission on the Choice on Termination of Pregnancy Act". 2007 - on file with author. "IPAS South Africa: Nearly Two Decades of Saving Women's Lives'. 2014.

$<$ http: / / www.google.co.za $/$ url? sa $=$ t\&rct $=$ j\&q $=\&$ esrc $=$ s\&frm $=1 \&$ source $=$ web $\&$ cd $=4 \& v e d=0 \mathrm{CC} 4 \mathrm{QFjADah}$ UKEwjl8fGnzfHIAhWJtBoKHXg5Dh8\&url=http\%3A\%2F\%2Fwww.ipas.org\%2F \%2Fmedia\%2FFiles\%2FSo uth-Africa\%2FSA\%2520overview.ashx\%3Fla\%3Den\&usg=AFQjCNHkfEMSMxkncjm2rgIaa2pSj2tV8A>. Accessed 1 November 2015.

REPRODUCTIVE RIGHTS ALLIANCE. "Submission to the Portfolio Committee on Health on The Termination of Pregnancy Bill”. 1996, on file with author.

. “Chairperson's Report to Members Meeting." December 2007, on file with author.

RRA BAROMETER “Undercounted as Gauteng excluded”. Vol. 7, May 2002. <http://www.hst.org.za/ sites/default/files/RRAbarometer_may2002.pdf>.

SMYTHE, John. "Moving Towards Improvement in SA Abortion

Legislation. Undated. <http://www.justicealliance.co.za/download/art-SA\%20Abortion\%20Legislation.pdf>. Accessed 1 November 2015 .

STEVENS, Marion. "Op-Ed: Womandla! Who can lead the ANC Women's League?" Daily Maverick. 6 August 2015.http: / / www.dailymaverick.co.za/article/2015-08-06-op-ed-womandla-who-can-lead-the-anc-women'sleague/\#.VcM_pvmqqko accesssed $6^{\text {th }}$ August 2015

WORLD HEALTH ORGANISATION (WHO). "Unsafe abortion: Global and regional estimates of the incidence of unsafe abortion and associated mortality in 2008”. 2008.

ZUMA, Jacob. "State of the Nation Address", 2015. http://www.gov.za/president-jacob-zuma-state-nationaddress-2015. Accessed, 5 August 2015.

\section{Official documents}

Christian Lawyers Association v Minister of Health 199811 BCLR 143 (T).

Christian Lawyers Association v Minister of Health 20051 SA 509 (T).

DEPARTMENT OF HEALTH. Annual Report of the Department of Health. 1975.

HANSARD, House of Assembly Debates, 1973.

\section{Cathi Albertyn}

Johannesburg - South Africa cathi.albertynawits.ac.za
PROFESSOR OF UNDERGRADUATE AND POSTGRADUATE COURSES ON PUBLIC LAW AND HUMAN RIGHTS AT THE UNIVERSITY OF the WitwatersRand, School of LaW.

BA LLB FROM THE University OF CAPE TOWN AND M.PHIL and PhD from Cambridge University IN THE UK. 